\title{
PENGUATAN ORGANISASI SEKOLAH MELALUI PENDEKATAN MUTU TERPADU
}

\author{
Oleh: Farid Hasyim*
}

\begin{abstract}
Yang terpenting dari organisasi sekolah adalah menciptakan proses pengajaran dan pembelajaran secara efektif dan efesien di sekolah, yang merupakan tugas pokok sekolah. Tanpa menyentuh aspek ini, maka organisasi sekolah tidak akan mempunyai arti penting dalam membangun sekolah delam melakukan proses pendidikan socara efektif. Beberapa penelitian yang efektif yang dikaitkan dengan proses organicasi selalu memberilan bagian penting dari peran manajemen sekolah dalam menciptakan iklim dan kultur sekolah yang efektif
\end{abstract}

\section{A. Pendahuluan}

Dewasa ini sekolah berkembang sebagai lembaga yang semakin kompleks sehingga ia membutuhkan organisasi yang tertata dengan dengan baik dan benar. Kompleksitas sekolah terutama terlihat dari kebutuhan akan mengelola pelaksanaan pendidikan dengan pendekatan menejemen. Itulah kebutuhan untuk menggunakan pendekatan ilmu manajemen di sekolah menjadi mutlak. Sehingga perkembangan administrasi pendidikan menjadi bagian yang menarik bagi kalangan praktisi dan ahli pendidikan sampai sekarang ini.

Bahkan laporan Bank Dunia dalam Indonesian in Education: From Crisis to Recovery (September 1998) menemukan bahwa aspek-aspek manajemen yang tidak efekif sebagai potensi penghambat kemajuan pendidikan, khususnya pada pendidikan dasar, yaitu sistem organisasi yang kompleks ditingkat pendidikan dasar, manajemen yang terlalu sentralistik pada tingkat SLTP, sistem pembiayaan pendidikan yang tidak efektif dan manajemen yang tidak efektif di sekolah (Supardi dan Djalal (Editor), 2001). Kompleksitas problematika pendidikan, dewasa ini, tidak saja hanya terpaku pada proses pengajaran dan pembelajaran, tapi lebih dari itu bagaimana membangun proses pembelajaran baik langsung maupun akan memberikan dampak pada peningkatan kualitas pendidikan. Proses inilah yang menjadi perhatian penting untuk melihat bagiamana hubungan antara berbagai komponen pendidikan dalam suatu sistem yang efektif dan efesien.

Hal ini sebagai akibat perkembangan sekolah sebagai bagian dari sistem sosial yang memberikan peran penting kepada sekolah dalam membangun kehidupan

Penulis adalah dosen Fakultos Tarbiyah CIIS Malang dan Mahasiswa Program Dokser LAIN Sunon Ampel Suraboyo 
sosial melalui pendidikan, pengembangan intelektual anak didik, mempersiapkan anak didik untuk memasuki kehidupan sosial (Husen, 1979; Goodlad, 1984; Balentine, 1990). Untuk itulah sekolah membutuhkan sistem organisasi yang efektif dan efesien dalam meningkatkan pencapaian tujuan atau sasaran yang telah ditetapkan. Sekolah semakin menjadi lembaga yang kompleks dengan berbagai kepentingan di masa depan dalam lembaga ini untuk meningkatkan kualitas pendidikan.

Adapun yang lebih penting dari organisasi sekolah adalah untuk menciptakan proses pengajaran dan pembelajaran secara efektif dan efesien di sekolah, yang merupakan tugas pokok sekolah (Campbell, Corbally \& Nystrand, 1983). Tanpa menyentuh aspek ini, maka organisasi sekolah tidak akan mempunyai arti penting dalam membangun sekolah delam melakukan proses pendidikan secara efektif. Beberapa penelitian yang efektif yang dikaitkan dengan proses organisasi selalu memberikan bagian penting dari peran manajemen sekolah dalam menciptakan iklim dan kultur sekolah yang efektif(Mortimer, Samon, Stoll, Lewis dan Ecob, dan Morgan dlm. Preeday, 1993). Kultur dan ethos sekolah akan mampu membangun keefektifan proses pendidikan yang dilakukan.

Sekolah sebagai sistem sosial (Hanson, 1991) adalah suatu upaya untuk memahami tujuan, peran ,hubungan dan prilaku berbagai komponen pendidikan di sekolah dalam setting sosial. Setidak-tidaknya ada dua elemen dasar yaitu: 1)institusi, peran dan harapan dalam menentukan norma bersama atau dimensi sosial, 2) individual, personalitas dan pemenuhan kebutuhan yang merupakan dimensi psikologis (Lipham, Rankin dan Hoeh, 1985). Di sini sekolah sebagai sistem sosial diharapkan mampu mencapai moral kerja anggota organisasi yang efektif, efesien dan memuaskan melalui integrasi kebutuhan individu dan kebutuhan organisasi.

Sekolah sebagai birokrasi (Rice \& Bishoprick, 11971; Hanson, 1991; Owen, 1991) dimana terjadi ada formalisasi, standarisasi, rasionalisasi, efisiensi dan efektifitas dalam menjalankan aktifitas organisasi. Tingkat birokrasi sekolah mungkin berbeda dengan birokrasi pemerintah, militer dan industri lainnya yang menuntut persyaratan yang cukup ketat dalam proses pengelolaan. Lain halnya dengan sekolah sebagai lembaga pendidikan yang mengarah pada pencapaian tujuan pendidikan yang intengabel, tidak nampak, bahkan tujuan pendidikan menjadi sulit tercapai dengan formalitas dan standarisasi. Karena yang dihadapi oleh pendidikan adalah keragaman tingkat pekembangan bakat, minat dan intelektual siswa, yang tentunya membutuhkan penanganan lebih fleksibel dan humanis.

Pelaksanaan pendidikan di sekolah merupakan aktifitas yang membutuhkan proses yang terorganisir secara sistimatis. Sekolah sebagai lembaga pendidikan tidak lepas dari berbagai komponen seperti guru, siswa, kurikulum dan saranaprasarana untuk terjadinya sebuah interaksi edukatif. Semua komponen tersebut merupakan sub sistem yang saling terkait, menguatkan dan saling mempengaruhi (Hanson, 1991:Preeday (editor), 1993) dalam suatu sistem untuk mencapai tujuan 
pendidikan itu sendiri.

Berbeda dengan organisasi industri dan jasa lainnya, bahwa sekolah mempunyai karakteristik khusus baik menyangkut misi, tujuan dan orientasinya. Sekolah sebagai lembaga yang bergerak dalam pengajaran dan pembelajaran lebih terfokus pada peningkatan kualitas intelektual. Proses pendidikan menjadi perhatian utama dalam sistem organisasi sekolah. Sehingga semua aktifitas sekolah diarahkan untuk meningkatkan prestasi siswa di sekolah baik yang berkaitan dengan harapan jangka pendek atau jangka panjang terhadap hasil pendidikan atau lulusan. Sistem organisasi sekolah tidak untuk menerapkan prinsip ekonomis dengan harapan pada tercapainya keuntungan ekonomi yang tinggi, tapi yang menjadi nilai kuntungan di sekolah adalah sangat bersifat non-profit berupa prestasi siswa.

\section{B. Konsep Dasar Organisasi}

Organisasi merupakan tempat terjadinya berbagai aktifitas sekelompok orang dengan tujuan yang sama. Untuk mencapai tujuan bersama ini dibutuhkan berbagai upaya-upaya sistimatis mulai dari penetapan tujuan, teknologi, pembagian tugas, pusat kekuasaan dan lingkungan (Rice dan Bishoprick; 1971). Rice dan Bishorprik (1971) mengungkapkan organisasi sebagai upaya untuk menjembatani harapanharapan organisasi (expectations of the organization) dengan harapan-harapan individual (expectations of the individual). Sedangkan Mc Gregor (1960)menyatakan bahwa harus terjadi integrasi tujuan perorangan dan tujuan organisasi, yang kemudian disebutnya sebagai teori Y. Sedangkan tinjauan aksiomatik tentang organisasi meliputi sasaran organisasi, sentralisasi, formalisasai, stratafikasi, tujuan organisasi, efesiensi dan kepuasan tugas(Hage dlm.Carver \& Sergiovanni, 1969).

Perkembangan organisasi yang berkembang selama ini menempati tiga teori utama yaitu teori birokrasi, teori sumber daya manusia, dan teori $\mathrm{X}$ dan $\mathrm{Y}$ (Owen, 1991). Sedangkan Rice dan Bishorprik (1971) menyebutkan ada tiga model organisasi yaitu model mesin, konsep-konsep homeostasis, dan model holistic. Model mesin sebagai model organisasi yang menekankan pada tingkat komfirmasi dan kepatuhan tinggi, perintah atasan bersifat diktatorship, yang mengakibatkan organisasi tidak efektif dan efesien. Berbeda dengan model mesin, model homeostasis lebih menekankan pada peranan anggota organisasi dalam meningkatkan atau mencapai tujuan, lebih bersifat manusiawi. Sedangkan model holistik ini melihat organisasi secara keseluruhan baik mencakup faktor ekonomi atau pun faktor sosial. Artinya model ini memadukan antara faktor-faktor bersifat mesin dan faktor-faktor bersifat manusiawi dalam suatu organisasi.

\section{Karaktersitik Organisasi Model Mesin}

Beberapa hal penting yang menjadi bagian penting dari model mesin pada 
organisasi yang juga sering disebut sebagai model teori tradisional, yaitu manajemen ilmiah dengan tokoh utamanya Frederick W.Taylor (1856-1915) dan birokrasi dengan tokoh utamanya. Max Weber (1864-1920). Teori manajamen ilmiah berangkat dari asumsi bahwa manusia dalam organisasi berkerja berdasarkan kebutuhan ekonomis. Sehingga ia perlu diupayakan proses kerja yang baik secara ilmiah untuk meningkatkan produktifitas kerja anggota. Sehingga standarisasi secara ilmiah pada keahlian pekerja, metode, tujuan, produktifitas dan efektifitas dan efesiensi harus didasarkan pada konsep ilmiah.

Organisasi dengan pendekatan ilmiah merupakan upaya untuk memahami pembagian authoritas dengan mengacu pada standar ilmiah dengan harapan dapat tercapainya produktifitas dan efsiensi lebih baik dalam mencapai tujuan organisasi. Dengan proses ilmiah dalam organisasi sangat mengabaikan aspek yang berkaitan dengan hubungan manusiawi yang terjadi pada aktifitas pekerjaan. Itulah sebabnya Frederick Taylor menetapkan beberapa prosudur untuk menganalisis pekerjaan antara lain:1) menggunakan eksperiment untuk menemukan cara terbaik dari suatu tugas, 2) menetapkan standar-standar untuk terciptanya cara paling efesien menyeleasaikan tugas, 3) perencanaan pekerjaan dengan menetapkan segala aspek yang berkaitan dengan suatu pekerjaan baik menyangkut sumber daya manusia, material dan sebagainya, 4) penjagaan atau mengonrol standar-standar agara tetap pada standar yang sudah ditetapkan agar tehindar dari factor manusiawi.

Sedangkan menurut Weber bahwa birokrasi yang ideal yaitu: 1)adanya penjenjangan kekuasaan yang authoritas didasarkan pada konfigurasi piramida, 2) pembagian kerja yang mengarah pada upaya untuk meningkatkan efesiensi, 3) kontrol dengan aturan, keputusan pejabat diarahkan dengan aturan 4) pembangunan hubungan yang impersonal, dimana kontrol terhadap anggota dan aktifitas organisasi mengenyampingkan aspek-aspek manusiawi agar lebih efesien dan murni seperti emosi, kepribadian, dan yang tidak rasional, 5) orientasi pada karir yang mengarah pada pekerjaan didasarkan pada keahlian, promosi didasarkan ada senioritas (Hanson, 1991).

Salah seorang tokoh birokrasi yaitu Henry Fayol (1841-1925) namun perbedaanya dengan Taylor yaitu Fayol menekankan pada pentingnya aspek kepemimpinan sedangkan Taylor menekankan pada aspek pekerjaan, Ada beberapa prinsip yang dikemukakan yang harus diketahui oleh manajer Fayol, yaitu:

1. memiliki pengetahuan yang lengkap tentang anggotanya

2. berupaya menghilangkan segala bentuk kelemahan.

3. menuliskan dengan jelas persetujuan yang dibuat organisasi dan pegawinya.

4. memberikan teladan yang baik

5. melakukan pemeriksaan keuangan secara periodic dan menggunakan gambaran tentang kesimpulan hasil pemeriksaan.

6. mengadakan pertemuan dengan pembantu-pembantu utama untuk 
membicarakan kegiatan yang diperlukan.

7. tidak banyak terlibat pada masalah yang kecil.

8. berusaha memupuk kesatuan, tenaga, inisiatif dan kesetiaan di kalangan anggota (dlm. Said, 1988: 31).

Akan menjadi peting bahwa untuk meningkatkan kinerja anggota organisasi memang mutlak dibutuhkan peranan seorang manajer yang mamapu mengelola keseluruhan aktifitas organisiai dengan baik. Seorang menejer diharapkan dapat memberikan peran proporsional dalam meningkatka efesiensi dan efektifitas organisasi dalam mencapai tujuan yang sudah ditetapkan.

\section{Karakter Organisasi Model Homeostasis}

Organisasi model homeostasis sebagi sebuah pendekatan dalam memahami pusat authoritas pada organisiasi. Pendekatan ini melakukan pemahaman pada kefektifan organisiasi akan terjadi apbila terjadi pembenahan aspek internal tanpa dipengaruhi oleh aspek eksternal. Itulah sebabnya pendekatan ini memberikan model-model pendekatan seperti; model egalitarian, model federasi, model collegial, model desentralisaisi dan model humanistic (Rice \& Bishoprick, 1971). Modelmodel ini merupakan upaya untuk melihat proses authoritas berlangsung dalam suatu organisasi.

Model egalitarian mempunyai asumsi bahwa untuk mencapai kualitas dalam suatu organisaisi harus didasarkan pada kesamaan authoritas. Untuk itulah seorang pimpinan organisasi harus menerapkan prinsip kesejajaran dalam menjalankan tugastugas yang akan diselesaikan untuk mencapai tujuan yang sudah ditetapkan. Model egalitarian menekankan pada kebebasan, demokrasi, dan kharisma manusia, menyediakan suatu sasaran organisasi pada kebutuhan sosial, ego dan pribadi yang harus dipenuhi, organiasasi tidak memperhatiakan aspek-aspek material yang dapat menjamin stabilitas, organisasi yang rasional dan ilmiah dalam mencapai keefeketifan organisasi dal;am mencapai tujuan. Untuk itul;a yang banyak ditekankan dalam model egelitarian adalah terjadinya kerjasama yang maksimal antara bawahan dan atasan.

Model federasi adalah model menekankan aspek spesialisasi suatu kelompok yang mempunyai atifitas kelompok yang telah ditetapkan untuk mencapai sasaran suatu organisasi. Model mempunyai asumsi bahwa suatu organisasi akan mencapai kualitas yang diharapkan tercapai apabila mampu membangun spesialisasi masingmasing kelompok dalam pekerjaan-pekerjaan tertentu. Model ini menekankan agar suatu organisasi memiliki sikap profesionalisme yang tinggi untuk dapat mencapai tugas organisasi secara maksimal.

Model collegial menunjuk pada bahwa untuk menciptakan produktifitas organisasi maka hendaknya terjadi hubungan antara bawahan dan atasan atas dasar keakraban profesional yang didasarkan pada spesialis masing-masing anggota 
organisasi. Model collegial organisasi ini dapat ditemukan pada universitas, dan rumah sakit, dimana bahwa integritas organisiasi terbangun didasarkan pada sikap profesional masing-masing individu dan kelompok pada organisasi, terutama sekali pada terciptanya hubungan antara semua komponen organisasi. Model desentralisasi ini menekankan bahwa produkifitas organisasi akan tercapai apabila organisasi memperhatikan perbedaan individual dalam memajukan organisasi. Sehingga model ini memberikan otonomi pengambilan keputusan kepada semua unit dalam organisasi secara penuh atas tanggung jawab masing-masing. Model humanistik adalah model organisasi yang memandang aspek manusia secara teknologis. Model ini menciptakan hubungan antara tujuan organisasi dengan tujuan-tujuan lainnya seperti kebutuhan individual, dan harapan individual. Upaya ini diharapkan dapat menciptakan pencapaian produktivitas organisasi secara efektif dn maksimal.

\section{Karakteristik Organisasi Model Holistik}

Berbeda dengan model mesin dan homestatistis yang telah dikemukakan lebih dahul, bahwamodel holistik melihat faktor ekonomi dan sosial sangat mempengaruhi berbagai kerjasama dalam suatu organisasi. Model berusaha untuk memadukan antara model mesin dan model humanistik dalam suatu organisasi. Ada beberapa model organisasi yang masuk dalam model holistik ini, yaitu model authorianisme, model administrasi publik, model sistem dan model modular (Rice dan Bishoprick, 1971).

Model authotarianisme merupakan model yang memberikan kekuasaan yang lengkap pada individu atau kelompok yang kemdian mendelegasikan kepada bawahan yang dianggap pantas untuk menerimanya. Model administrasi publik merupakan model yang menetapkan komite atau kelompok yang dipilih untuk mengorganisasikan suatu upaya untuk mencapai suatu tujuan organisasi. Model sistem melihat bahwa organisasi merupakan suatu sistem yang terdiri dari berbagai subsistem yang saling tergantung dalam mencapai tujuan organisasi (Rice dan Bishoprick, 1971; Hanson, 1991). Model Modular merupakan modifikasi dari model sistem, yang menekankan pada terjadinya modul interaksi hirarkis administratif dan penetapan kebijakan organisasi yang saling terkait dalam suatu komunikasi.

\section{Organisasi Sekolah dan Implementasi Visi Pendidikan}

Organisasi sekolah sebagai lembaga non-profit dalam bidang pendidikan, belakangan ini, menjadi perhatian semua pihak yang berkepentingan dengan hasil pendidikan. Lebih-lebih bahwa sekolah merupakan sistem sosial yang tidak lepas dari lingkungan yang dimilikinya. Keberhasilan sekolah untuk mencapai tujuan pembelajaran dan pengajaran tidak lepas dari peran semua komponen pendidikan. Dalam tinjauan administratif bahwa sekolah sebagai sistem sosial berlangsung struktur birokrasi yang dengan karakteristik khusus yaitu; 1) berorientasi tujuan; 
sekolah mempunyai tujuan, 2) Struktur hirarkis; kekuasaaan yang ada secara formal antara atasan dan bawahan yang jelas, 3) Struktur organisasi; fungsi dan proses yang dipahami dalam hubungan peran dan prosudur untuk mengatur dan mengevalusai aktifitas organisasi (Lifham, Rankin \& Hoeh, 1985).

Sekolah sebagai organisasi tentu tidak lepas dari berbagai aktifitas yang berkaitan dengan upaya menciptakan efesiensi dan keefektifan pencapaian tujuan pendidikan. Atas dasar inilah sekolah membutuhkan pendekatan organisasi yang memungkinkan bagi terciptanya iklim sekolah yang mendukung tercapainya proses pembelajaran dan pengajaran yang baik. Sementara sekolah dipahami seperti organisasi industri akan memberikan dampak yang kurang menguntungkan bagi proses pendidikan itu sendiri. Hal ini didasarkan pada tingginya unsur manusiawi dalam sekolah, yaitu bangunan kelembagaan harus ditujukan pada tercapainya kualitas lulusan peserta didik yang diharapkan. Sehinggan faktor-faktor manajerial, pengajaran dan pembelajaran harus mengarah pada meningkatnya kualitas lulusan. Kepemimpinan kepala sekolah, pengelolaan sumber daya manusia dan sumber daya ekonomis hendaknya mengarah pada terciptanya proses pengajaran dan pembelajaran yang efektif dan efesien. Sehingga sasaran utama dari sekolah untuk meningkatkan pengembangan intelektual siswa dapat tercapai dengan baik melalui proses pendidikan.

Akhir-akhir ini bahwa sekolah berkembang dengan sebuah sistim organisasi yang lebih maju seiring terjadinya perubahan paradigma organisasi modern. Apabila organisasi dengan pendekatan manajemen ilmiah, birokrasi, dan sebaginya lebih menekankan pada distribusi kekuasaan (authority) kepada semua unit organisasi yang sangat birokratis, maka pendekatan terbaru dewasa ini lebih terfokus pada membangun kultur sekolah (Preedy, 1993; Murillo,2002; Caldwell \& Spinsk, 1993) dan sistem birokrasi yang fleksibel namun tetap mengarah pada upaya tercapainya tujuan pendidikan. Sekolah tidak lagi sebagai sebuah organisasi dengan komponenkomponen intermal semata, tapi juga sangat dipengaruhi dengan aspek lingkungan sekitamya. Sehingga pendekatan baru dalam meningkatkan kualitas menejemen sekolah menjadi kebutuhan utama yang diakibatkan oleh perkembangan paradigma tentang pendidikan dan sekolah itu sendiri. Apabila sebelumnya sekolah hanya merupakan urusan pemerintah, sekarang telah berkembang bahwa sekolah menjadi bagian dari sistem sosial yang melibatkan unsur-unsur masyarakat untuk memajukannya. Sehingga sebelumnya sekolah serat dengan sistem sentralisasi sehingga pengembangan sekolah sulut dilakukan dalam tingakt local seklah.

Untuk menciptakan organisasi sekolah yang efektif sesungguhnya diharapkan pada perubahan paradigma sekolah sebagai lembaga pendidikan. Upaya ini dapat dilakukan dengan memperhatikan tugas utama sekolah yaitu untuk memberikan pendidikan kepada siswa. Untuk menciptakan sekolah sebagai organisasi yang baik dan efektif maka dibutuhkan upaya menejerial berdasarkan pada konteks kultur 
sekolah, yang tentunya mempertimbangakan aspek manajemen untuk meningakatkan kualitas proses pendidikan di sekolah. Untuk itulah kulitas guru, kepemimpinan kepala sekolah, siswa, orang tua dan masyarakat perlu mempunyai andil masing-masing dalam meningkatkan keefektifan manajemen sekolah.

\section{Sekolah: Pendekatan Menejemen Mutu Terpadu}

Manajemen mutu terpadu merupakan salah stau upaya untuk melihat sekolah dalam sustu kestuansistem yang terkait dengan komponen-komponen pendidikan lainnya. Model menejemen ini memandang perlunya membangun hubungan yang kuat antara pihak sekolah dengan masyarakat yang membutuhkan sekolah yang memilki jaminan mutu. Dalam pendekatan ini bahwa ada beberapa komponen organisasi sekolah yang harus memiliki yaitu visi sekolah, kepemilikan dan komitmen, kepemimpinan kepala sekolah, orang tua dan siswa sebagai pelanggan, pemberdayaan guru (Mugatroyd \& Morgan, 1992).

Manajemen mutu terpadu merupakan upaya untuk meningkatkan kualitas pendidikan dengan memperhatikan semua unsur yang terlibat dalam sekolah sebagai pihak yang bertanggung jawab dalam meningkatkan kualitas pendidikan. Apakah mereka berada pada organisasi sekolah secara langsung atau diluar sekolah. Untuk itulah ada beberapa hal yang perlu diperhatikan dalam konsep manajemen mutu terpadu, yaitu:

\section{Visi Sekolah}

Visi sekolah merupakan unsur utama dalam organisasi, yang akan menggerakkan ke mana sekolah akan memusatkan segala aktifitasnya. Sekalipun visi sangat bersifat abstrak dalam bentuk suatu harapan dan nilai yang kan dicapai organisasi, tapi mampu mewarnai kultur dan iklim organisasi. Sehingga sekolah yang mempunyai visi organisasi yang jelas akan mampu untuk merencanakan serangkaian akitifitas organisiasi menuju tercapainya visi tersebut. Visi sekolah sebagai pengemaban visi pendidikan hendaknya memberikan warna yang kuat pada sekolah agar semua aktifitas pendidikan untuk meningkatkan kualitas siswa. Sehingga upaya-upaya proses manajemen dalam sekolah baik yang menyangkut efesiensi dan efektifitas tidak mengurangi arti penting pelaksanaan pendidikan, utamanya bagi peningkatan kualitas pengajaran dan pembelajaran yang akhimya akan bermuara pada peningkatan mutu pendidikan .

Untuk itulah bahwa visi yang baik mempunyai karateritik meliupti; menantang, mudah diingat, dapat menggerakkan oragnisasi, dapat visuakan, mobilisasi kebutuhan, dapat diterjemahkan sebagai arah aktifitas sehari-hari, berkaitan dengan kebutuhan siswa. Visi yang baik akan dapat menciptakan iklim organisasi yang dibutuhkan untuk mencapai tujuan sekolah. 


\section{Komitmen Pada Sekolah}

Visi sekolah yang baik tentunya kan menumbuhkan rasa komitmen semua anggota organisasi terhadap sekolah itu sendiri. Sikap seperti ini tentunya akan diharapkan dapat menciptakan iklim dan budaya sekolah yang positif bagi pertumbuhan sekolah. Sehinggan diharapkan dengan komitmen yang tinggi dapat memberikan upaya untuk membangun strategi dalam meningkatkan kualitas organisasi sekolah. Kepala sekolah hendaknya mebangun komitmen semua anggota organisasi seperti guru, siswa, staf dan orang tua.

\section{Kepemimpinan Kepala Sekolah}

Masalah kepemimpin sekolah memang menjadi perhatian banyak ahli manajemen pendidikan dewasa ini. Kepala sekolah mempunyai peranan penting dalam meningkatkan kualitas proses pendidikan (Mourgatroyd \& Morgan, 1992; Caldwell \& Spink, 1993). Untuktulah diharapkan kepala sekolah memberikan peran maksimal dalam melaksnakan tugas-tugas dan tangung jawab organisasi di sekolah.

Aspek penting yang perlu diperhatikan dalam kepemimpinan yaitu visi sekolah, komitmen, budaya, komunikasi yang didukung dengan strategi dan tujuan, team kerja yang profesional dan alat-alat yang digunakan untuk memperlancar efeketifitas dan efesiensi kepemimpinan. Kepala sekolah hendaknya mampu membangun komitmen anggota organisasi sekolah untuk mencapai tujuan organisasi secara bersama-sama.

\section{Pemberdayaan Guru dan Staff}

Pemberdyaan guru dan staf merupakan bagian penting yang harus diperhatikan dalam sekolah. Guru sebagai tulang punggung pendidikan di sekolah harus mendapatkan perhatian dalam mengebangkan profesionalisme dalam pengajaran dan pembelajaran. Pemberdayaan guru dan staf hendaknya mengarah pada terciptanya upaya membangun tecapainya pendidikan. Khususnya guru sebagai pihak yang melakukan proses pendidikan di sekolah layanan pengembangan profesi yang memadai untuk meningkatkan kualitas pengajaran dan pembelajaran di kelas. Upaya-upaya ini dapat dilakukan dengan meningkatkan intensitas supervisi pendidikan sebagi bentuk layanan professional dalam rangka mengembangkan dan meningkatkan kualitas proses pendidikan.

\section{Komunitas Orang tua dan Komunitas Siswa}

Bagian penting yang berkaitan dalam manajemen mutu terpadu adalah keterlibatan orang tua, siswa dan masyarakat dalam upaya untuk meningkatkan kualitas pendidikan (Mulyasa, 2002; Caldwell \& Spinks, 1993). Komunitas orang tua dan siswa hendaknya terlibat langsung dalam proses pengelolaan sekolah, 
terutama dalam proses pembuatan keputuasaan. Hal ini dilakukan sebagai upaya meningkatkan komitmen, rasa memiliki dan tanggung jawabnya dalam peroses pendidikan di sekolah.

Sementara yang berkembang dalam menejemen sekarang ini adalah bagiamana melibatkan orang tua dan masyarakat dalam menyiapkan dana yang cukup bagi pelaksanaan pendidikan. Masalah utama adalah meningkatkan dana pendidikan baik dari orang tua dan masyarakat untuk mendukung pendidikan di sekolah. Dan ini tentunya akan mengatasi bagian sekunder dari pendidikan, yang seharusnya ditekankan adalah upaya untuk mengelola sekolah dalam upaya terwujudnya poses pembelajaran dan pengajaran yang efektif dan efesien.

\section{Daftar Rujukan}

Ballatine, Jeanne H. 1993. The Sociology of Education: a Systematic Analysis. New Jerssey: Prentice-Hall.

Bishorick, Dean, W dan Rice, George H. 1971. Conceptual Model of Organization: USA. Merdeth Corporation.

Caldwell, Brian, J. dan Spink, Jim M. 1993. Leading The Self-Managing School: London. The Falmer Press.

Campbell, Roald, F., Cobally, J, dan Nystrand, Raael, O. 1983. Intruduction To Educational Administration: Toronto. Allyn and Becon.

Hanson, Mark, E. 1991. Education Administration and Organizational Behavior:London. Allyen and Bacon.

Husen.T. 1979. The School in Question: New York. Oxford Press..

Jalal dan Supriadi (Editor). 2002. Reformasi Pendidikan Dalam Era Otonomi

Daerah: Jakarta. Dediknas. Bappenas. Adicitakarya

Lipham, James, Rankin, R, dan Hoeh, James. 1985. The Principelship. New York. Longman.

Morgatroyd, S, dan Morgan, C. 1992. Total Quality Management and School;USA. The Open University.

Mulayasa. E. 2002. Manajemen Berbasis Sekolah. Jakarta . Rosdakarya Murillo, Javier, F. 2002. Good Effective School Improvement Practice in Spain.

Educational Research and Evaluation, Vol. No.4 . pp. 387-410.

Owen, Robert G. 1991. Onganizational Behavior In Education: Toronto. Allyn and Bacon.

Preedy, Margaret. 1993. Managing The Effective School. London. Open University 